\title{
THE ADOPTION OF ACTIVITY-BASED COSTING IN PRIVATE HEALTH CARE FACILITIES IN SOUTH AFRICA
}

\author{
Gideon Botha* \\ University of Pretoria
}

Received: November 2016

\author{
Elda du Toit* \\ University of Pretoria
}

Accepted: January 2017

\begin{abstract}
The implementation of a South African National Health Insurance, combined with the potential of price reforms, has the potential to adversely affect the profitability of the health care industry. This could force management to look at ways to better understand the causal link between costs and the activities that drive costs. The study aimed to determine the extent of $A B C$ use in health care facilities in South Africa, what the perceived and actual benefits are of adopting $A B C$ and what other management tools and techniques are considered important. A structured questionnaire was sent to a target population, to which $51 \%$ of recipients responded. The results revealed that the rate of $A B C$ adoptions has increased from $1.2 \%$ in 1994 to approximately $46 \%$ today. The growth in $A B C$ adoptions and the high level of $A B C$ adoption in relation to hospitals in the USA and Ireland indicate that the hospital industry in South Africa acknowledges the value $A B C$ can add.
\end{abstract}

Keywords

Activity-based costing, $A B C$, health care facilities, National Health Insurance, health care costs, profitability, management tools and techniques

*Mr G Botha is a master's student in the Department of Financial Management, University of Pretoria, South Africa.

\#Dr $\varepsilon$ du Toit is a senior lecturer in the Department of Financial Management, University of Pretoria, South Africa. [elda.dutoit@up.ac.za] 


\section{INTRODUCTION}

Worldwide, health care systems struggle with increased costs and an uneven distribution of health care quality, despite the best efforts of well-trained health care workers (Porter and Lee, 2013, Llewellyn and Northcott, 2005, Tang, Tao and Bekedam, 2012). Many countries have been, and are, in the process of implementing national strategies and policies towards health care for all citizens. While the quality of health care and treatment has improved to such an extent that the average life expectancy of humans are on the increase in many populations (Kaplan and Porter, 2011, Salomon et al., 2013), the work and leisure environment has changed in the new millennium to one where people tend to be sedentary most of the time, which increases instances noncommunicable chronic diseases (Tang et al., 2012). In addition, various health care challenges still abound in undeveloped areas, such as AIDS, antibiotic-resistant tuberculosis and malaria. (Akay and Tamura, 2015). All these factors increase the need for governments' continued monetary investment in health care.

In the USA, health care currently exceeds $17.1 \%$ of GDP and continues to rise. Even countries that spend less of their GDP on health care are experiencing increased health care costs (Kaplan and Porter, 2011, The World Bank, 2014). At 8.9\%, South Africa spends just over half as much of its GDP on health care than the USA, but South Africa faces a twofold problem (The World Bank, 2014). Firstly, the cost of health care is on the rise and, secondly, around $5 \%$ of the GDP spent on health care caters only for the 7 million people who can afford private health care. The $3.9 \%$ that remains has to cater for approximately 41 million people. This leads to a largely uneven distribution of the quality of health care provided to the South African population (Bateman, 2010).

The rise in the cost of health care has led to the launch of a market inquiry by the South African Competition Commission into the health care industry. The Competition Commission makes recommendations to regulate and support affordable and quality health care, which could have an impact on health care policies. These recommendations include acceptable mechanisms to set prices (Makholwa, 2013a). Dr Motsoaledi, the South African Minister of Health, has furthermore indicated that a health commission could be set up to regulate prices in the health care industry, but this is subject to the recommendations of the Competition Commission (Makholwa, 2013b).

Given this, one can expect that governments would prefer to have more control over hospital costs and the medical profession. Hence, the introduction of the National Health Insurance (NHI) in South Africa, a project the South African Government decided to introduce to address the uneven distribution of quality health care between the private and public health care sector. The NHI is to be phased in over a 14-year period, with the first pilot sites launched in 2012. The aim is that the $\mathrm{NHI}$ will be financed through an additional tax of between $3.5 \%$ and $5 \%$ on salaries and wages (Wasserman, 2010). The impact that this will have on the number of people who can afford private medical aid can only be determined once the $\mathrm{NHI}$ tax is levied, but there is the potential that the number of medical aid members will decrease due to financial constraints imposed by the additional tax.

Changes in the costing of health care and medical treatment are inevitable (Porter and Lee, 2013). Cost containment and cost management are perceived to be the ideal way to deal with health cost issues (Doyle, Duffy and McCahey, 2007). The use of Activity Based Costing (ABC) proposes a possible solution to inaccurate costs and unfair prices for treatments by consistent and accurate allocation and calculation of costs. $A B C$ considers individual costs and traces those directly to activities performed. The accurate information that is derived from an $A B C$ costing system will lead to more accurate prices charged and thus reduces the risk of contravention of laws around 
unfair competition (Udpa, 1996, Doyle et al., 2007, Ross, 2003, West and West, 1997). Establishing the adoption rate of international management tools such as $A B C$ will provide key insights into the health care industry's readiness to face the challenges of the $\mathrm{NHI}$ and the competition commission.

This study aims to establish the extent to which $A B C$ is used in the health care industry of South Africa as a way to address inconsistent and inaccurate cost allocation and cost calculation. The research questions to be answered by this study are:

- Do private health care companies in South Africa make use of $A B C$ ?

- What are the perceived and realised benefits of companies that do adopt $A B C$ ?

- What problems are generally experienced through the adoption of $A B C$ ?

- What other management accounting techniques are considered useful or important in cost allocation and calculation?

The next part of the study is a review of the literature to provide background not only on the health care industry of South Africa, but also the use of $A B C$ in the health care industry. Thereafter the research method is described, followed by the research results and a discussion thereof.

\section{LITERATURE REVIEW}

Ross (2003) and Kaplan and Porter (2011) argue that the biggest cause of high health care costs is the use of poor costing systems that cannot accurately measure the cost per health care procedure. If the cost of resources consumed to perform a health care procedure cannot be accurately measured, these costs cannot be effectively managed. This was also the finding in the UK, where a drive towards standardisation of costs, through averaging, was initiated (Llewellyn and Northcott, 2005). Average costs can be implemented both for control over hospital cost and the medical profession. According to Kaplan and Porter (2011) the accurate measurement of costs and outcomes is the most influential advantage to revolutionise the economics of health care.

Since hospitals offer a variety of services and need to allocate costs in a different way for most patients, Activity Based Costing ( $A B C$ ) is perceived to be ideal for the hospital environment (Udpa, 1996, Doyle et al., 2007, Ross, 2003, King et al., 1994, Pandey, 2012). Both the standardisation of costs and averaging can be implemented in an $A B C$ costing system and non-value adding activities can be identified and improved (West and West, 1997). Direct costs to treat a patient, such as medicine and theatre use, can be directly allocated to individual patients. Difficulties arise in the allocation of overhead-and administration-related costs. In traditional costing systems, these costs would be allocated on the basis of a single cost driver, for example the number of days a patient is in hospital. The use of an $A B C$ costing system can ensure that overheads and administration costs are allocated to patients in a way that is more related to the treatment the patient received, rather than an arbitrary amount based on the number of days the patient was in hospital. Eldenburg et al. (2010) found that resources are used more efficiently in an $A B C$ system, provided that users participated in the development and implementation of the system.

A difficulty identified by Llewellyn and Northcott (2005) is the various ways in which efficiency can be influenced, namely (1) differences in the unit cost of resources, (2) differences in the running costs of hospitals, and (3) differences in the clinical practices in a particular hospital. 
This problem can be addressed through the use of $A B C$, since $A B C$ improves the insight into the activities that drive costs and furthermore allows for the true cost per procedure to be calculated (Pandey, 2012). One should note, however, that $A B C$ only improves the process of cost allocation and calculation and thus only provides more accurate information. It cannot do anything towards the control of costs, apart from the provision of more accurate information on processes to highlight areas of concern which can lead to positive changes towards better effectiveness and efficiency (Ross, 2003, King et al., 1994, Kaplan and Porter, 2011).

Ramsey (1994) argues that an effective costing system for a health care facility should accomplish three main goals: it should promote cost efficiency without sacrifice to the health care facility's service quality; it should allow the health care facility to maximise its resources; and it should highlight opportunities for continuous improvement of the health care facility's operations. Ross (2003) suggests that $A B C$ has the potential to improve managers' cost awareness, which leads to better cost, demand and quality management in the health care environment. Udpa (1996) claims that, with greater emphasis placed on pricing, there is a need for more accurate costing information and cost management and this, in turn, necessitates the development of new costing systems. Doyle et al. (2007) found that more accurate cost information, better resource management, and improved performance management are the three most important reasons cited for the adoption of $A B C$ in health care facilities in Ireland. According to Pizzini (2006), managers believe that, when they have better cost detail, they can make better decisions, which lead to better profitability, better cash flow and lower administrative costs.

The three primary reasons health care facilities in the USA adopt ABC, as found by Lawson (2005), were to control costs, improve processes, and provide more useful cost information. Surveys conducted by Doyle et al. (2007) and Lawson (2005) support the reasons health care facilities adopt $A B C$, as cited by Ross (2003) and Udpa (1996). From the abovementioned arguments it is clear that $A B C$ has the potential to meet all three key objectives identified by Ramsey (1994).

The level of $A B C$ adoption in the health care industry has not been as well documented as in the manufacturing industry. A study conducted in the USA by Lawson (2005) found that the ABC adoption rate during 1994 was $16 \%$, decreasing to $14 \%$ during 1999 . $A B C$ adoption in the health care sector is far below the survey results of the top 500 Fortune Companies that showed a $52 \%$ rate of $A B C$ adoption (Kiani and Sangeladji, 2003) and is $6 \%$ lower than the adoption rate of $20 \%$ in the health care sector in the USA and Canada as found by West and West (1997). The adoption rate found by Lawson (2005) is also much lower than the adoption rates reported in a survey conducted in Ireland by Doyle et al. (2007). In this survey, $55 \%$ of the respondents indicated that they have adopted $A B C$, while the majority of those respondents $(83 \%)$ indicated that they adhered only to the basic principles of $A B C$ and have thus not fully implemented an integrated system (Doyle et al., 2007). After making an adjustment to the initial rate to reflect only the minority of respondents who have fully implemented $A B C$, the true adoption rate of $A B C$ falls to only $9 \%$ of the total respondents in the survey. This is $5 \%$ lower than the level of adoption found by Lawson (2005). In South Africa, the ABC adoption rate in the health care industry was found to be $1.2 \%$ during 1994 (Viljoen, 1994).

Despite all the benefits that have been documented on the adoption of $A B C$ within the health care industry, the level of adoption is extremely low. This low adoption rate is largely attributed to the difficulties associated with the implementation of $A B C$. One of the biggest problems health care facilities face when implementing $A B C$ is the collection of data to set up the $A B C$ system, as it is time consuming and expensive (Udpa, 1996). King et al. (1994) found the complexity to define 
cost pools and to identify activity drivers in health care facilities to be a further hurdle in the adoption of $A B C$.

Doyle et al. (2007) found the top four problems in the adoption of $A B C$ to be (1) difficulty associated with the information system, (2) inadequate computer support to implement the system, (3) difficulties to select cost drivers, and (4) lack of adequate resources to effectively implement $A B C$. The top four problems identified by Lawson (2005) were: selling the concept of $A B C$ to middle management, selection of cost drivers and defining distinct activities, inadequate computer support, and allocation of costs in a manner that reflects cost causation. The biggest difference between the two surveys was that Lawson (2005) identified difficulty in selling ABC to middle management as a problem, whereas Doyle et al. (2007) did not encounter this issue. Lawson (2005) found the three most-cited reasons for non-adoption of $A B C$ in order of importance to be: the cost to design and implement an $A B C$ system; belief that it would be necessary to create a new system for data capturing and processing; and a lack of senior management's commitment to ABC. Doyle et al. (2007) found the three most cited reasons for non-adoption to be: the cost to design and implement $A B C$; a belief that it would be necessary to create a new system for data capturing and processing; and the high level of complexity associated with $A B C$.

In addition to $A B C$ as a possible management accounting tool that can provide better cost data, managers of health care facilities are faced with a variety of other tools and techniques. In the sections that follow, the methods that are most familiar and most often used in the health care industry of South Africa are briefly described. These include (in alphabetical order):

- Balanced scorecard

- Benchmarking

- Break-even analysis

- Budgeting

- Performance management

- Reengineering or business process reengineering (BPR)

- Risk assessments

- Six Sigma

- Target costing

- Total quality management

A balanced scorecard is a strategic planning and management system to align all business processes to the vision and strategy of the organisation. It is widely used in business, government and non-profit organisations (Niven, 2011). The balanced scorecard is often used in organisations as a general overarching model together with other management accounting models (Hoque et al., 2012).

Benchmarking is the process of comparing a company's business processes to other companies in the industry or to observe the best practices employed by other companies. Benchmarking is most often performed for operational processes, strategic priorities and management processes (Chenhall and Langfield-Smith, 1998). This can be used as a technique to manage an organisation's processes in order to facilitate continuous improvement.

Break-even analysis is an important tool to establish business performance and profit planning. Break-even analysis (also known as cost-volume-profit analysis) uses the fundamental 
relationships between costs and revenues to establish the minimum sales an organisation needs to make to generate profits (Alhabeeb, 2012, Tsorakidis et al., 2011).

Budgeting is a process of forecasting expected income and expenses for purposes of planning and control (Kaplan and Norton, 2001). There are various budgeting techniques, and most organisations still implement some form of budgeting despite recent advances in management accounting (Garg et al., 2003).

Performance management is a method of organisational management which includes activities to ensure that organisational goals are constantly met effectively and efficiently. Originally a concern for the human resources department of an organisation, performance management has evolved into a critical strategic management tool (De Waal, 2013). The focus of performance management is mostly on the individual employee, to ensure that each task is completed in a way that will benefit the organisation and help it to meet its goals (Gruman and Saks, 2011)

Reengineering or business process reengineering (BPR) is a strategy for business management which focuses on a detailed analysis and design of the workflow and processes of an organisation (Chiarini, 2012). Developed in the 1990s with most of the research on the concept performed at that time, business process reengineering involves a fundamental rethink of the way work is performed in order to improve customer service, reduce costs and compete effectively.

Risk assessments or enterprise risk management (ERM) relate to a system of regular review of an organisation's activities in order to identify possible areas of risk. It is considered to be a critical factor in the success of an organisation (Cescon, Constantini and Rossi, 2013). The implementation of an enterprise risk management system is often affected by the regulatory environment, internal factors, ownership structure and various other industry-and organisationrelated factors (Paape and Speklè, 2012).

Six Sigma is an approach and methodology for process improvement with a focus on the elimination of defects. It is based on the premise that there may only be six standard deviations between the mean and the nearest specification limit in any process, from manufacturing to after-sales service (Evans and Lindsay, 2014). Six Sigma has been implemented in various business arenas, as illustrated in Swink and Jacobs (2012), as well as Gupta and Kumar (2014).

Target costing refers to a specific costing technique where a product or service is designed to fit into a particular range of costs (Burrows and Chenhall, 2012). The origin of the concept dates back to the 1960s. A target sales price is established by means of market research. The company's target profit is deducted from that and the target cost of the product is derived.

Total quality management (TPM) is a management approach that was developed in the 1950s and has become more popular since the 1980s. Total quality management refers to a culture and attitude in an organisation that strives to provide customers with products and services that not only satisfy expectations, but also exceed them (Richards, 2012). It relates to the concept of continuous improvement of products, processes and services. It is important that every part of an organisation is permeated with the ideas of total quality management for it to be a success (Dereli et al., 2011).

Many of the tools and techniques mentioned here can be used in conjunction with other tools and techniques and can thus act as enhancements to an $A B C$ system.

The next section describes the research method implemented for the collection and analysis of data. 


\section{RESEARCH METHOD}

The aim of this cross-sectional study is to investigate various aspects about the adoption of Activity Based Costing (ABC) in the health care industry of South Africa. The study is empirical in nature and makes use of questionnaires and subsequent numerical data analysis to measure various aspects of $A B C$ adoption in the health care industry in South Africa. The study can thus be defined as a quantitative research study.

This study makes use of primary data, as the only available data was previously collected by Viljoen (1994). Due to the changes in the health care industry since 1994 and the length of time since the data was collected, the secondary data could not be used as it would not provide an accurate representation of the current health care landscape.

\subsection{Data collection strategy}

The survey strategy employed for the research study allowed for a large geographical area and large sample to be covered in a cost- and time-effective manner. Also, as the study is a replica study of surveys conducted by Doyle et al. (2007) in Ireland and Lawson (2005) in the USA, a survey strategy had to be followed to allow comparison between the results of this study with the results found in Ireland and the USA.

The survey was conducted by means of a self-administered online questionnaire that was sent to a judgemental sample. A self-administered online questionnaire is preferable to face-to-face and telephonic interviews, as these alternative methods are too costly and time consuming, taking into account the large sample and geographical layout of the various health care facilities. Furthermore, self-administered, online questionnaires decrease the likelihood of contamination or distortion of respondents' answers (Lewis, Thornhill and Saunders, 2007).

Below are some of the limitations of the chosen study method:

- With standardised question items that are at least minimally appropriate to all respondents, one may miss what is most appropriate to many respondents (Babbie, 2015).

- The research strategy is dependent on the goodwill of the respondents for information (Lewis et al., 2007).

- Once surveys have been designed, they are very rarely changed during the research study, whereas direct observation strategies can be modified as required by field conditions (Babbie, 2015).

- Surveys cannot measure social actions. Surveys can only collect self-reports on past actions or prospective or hypothetical actions (Babbie, 2015).

The respondents were asked to rate different statements about activity based costing and management accounting methods by means of a five-point Likert scale (1: Strongly Disagree, 2: Disagree, 3: Neither Agree nor Disagree, 4: Agree, 5: Strongly Agree). A Likert scale was used so that the results of the study could be compared with the results from the surveys of Doyle et al. (2007) and Lawson (2005).

\subsection{Sample size}

As the study was a replica of the surveys done by Doyle et al. (2007) in Ireland and Lawson (2005) in the USA, the sample sizes of these two surveys were used as a guideline to determine the 
appropriate sample size of the study. The sample size used by Viljoen (1994) could not be used as a guideline due to the changes in the health care facility landscape since 1994.

Doyle et al. (2007) sent out questionnaires to 60 financial controllers in Irish health care facilities and Lawson (2005) sent questionnaires to 404 chief health administrators of health care facilities in the USA. The sample size for this study was 81 health care facilities in South Africa. The sample is seen as a fair representation of the current hospital landscape and is large enough to decrease the likely error of generalisation to the population (Welman, Kruger and Mitchell, 2005).

\subsection{Response rates}

The questionnaire was distributed to the financial manager, chief financial officer or group financial controller of the various hospitals. Responses were obtained from 41 respondents. This translates to a response rate of $51 \%$, which is higher than the $36 \%$ response rate in the study by Doyle et al. (2007) and the $14.5 \%$ that was achieved in the study by Lawson (2005).

Even though the response rate is relatively high, the sample size still remains low. For most statistical tests, the power of a test increases with the number of observations. For that reason this study uses mostly descriptive statistics in order to illustrate the findings from the survey without the risk of Type I or Type II errors as a result of the small sample size.

\section{RESULTS}

This section provides a detailed review of the results that were obtained from statistical analysis of the data from the different health care facilities. It is divided into categories according to the research questions identified in the introduction to the study.

\subsection{The level of $A B C$ adoptions}

Basic descriptive statistics were calculated to test the adoption rate of $A B C$ in health care facilities in South Africa. The results are reported in this section.

The results from the health care facility respondents indicated that $46 \%$ of health care facilities adopted $A B C, 22 \%$ currently consider $A B C$ and $32 \%$ do not currently consider $A B C$. Over the past twenty years there has been a general growth of $29.8 \%$ in the adoption rate of $A B C$, which can be considered significant. The adoption rate of $46 \%$ in South Africa is higher than the adoption rate of $14 \%$ found by Lawson (2005) in the USA and the effective rate of $9 \%$ found by Doyle et al. (2007) in Ireland.

The high adoption rate could be attributed to the following factors:

- Luther and Longden (2001) found that the following factors has driven the change in management accounting in South Africa since 1994: (1) increased uncertainty about the economic environment in South Africa, (2) a shortage in the availability of competent staff, (3) the removal of barriers to trade, and (4) the increased cost of input.

- Kaplan and Cooper (1997) argue that the higher the level of indirect cost, the higher the potential benefits that can be realised from the introduction of $A B C$. Based on their argument, it seems that the health care industry is ideally suited to realise the maximum actual benefits from the adoption of $A B C$, because the highest portion of the total costs of 
health care facilities is fixed costs at $55 \%$, of which $30 \%$ is salary costs and $15 \%$ materials (Viljoen, 1994).

The rate of $22 \%$ of respondents who are considering the adoption of $A B C$ at a health care facility indicates that the adoption rate of $A B C$ may still rise in the foreseeable future. The percentage of health care facilities that consider the adoption of $A B C$ is significantly higher than in the USA, where only $7 \%$ of the respondents indicated that they are considering adopting $A B C$ in future (Lawson, 2005). It is important to understand why the health care facilities and hospital groups consider the adoption of $A B C$, as this will give an indication as to the direction of the overall industry.

The reasons cited at a group level and at a health care facility level for considering adopting ABC are largely similar. One group has identified more reasons than the other in their considerations to adopt $A B C$, which indicates a higher appreciation of the potential benefits of $A B C$. One group wants to adopt $A B C$ for improved negotiations with medical aid companies, whereas neither of the other two groups cited this as either a reason to adopt $A B C$ or as a reason to consider the adoption of $A B C$.

The three most important reasons identified by those respondents who do not consider the adoption of $A B C$, in order of importance, were: the belief that it would be necessary to create a new system for data capture and processing, that $A B C$ is too complex, and that it is too difficult to develop suitable cost drivers and cost pools. According to the Likert scale used, TABLE 1 presents the frequencies of responses for each statement.

TABLE 1: Reasons not to adopt ABC

\begin{tabular}{|c|c|c|c|c|c|}
\hline $\begin{array}{l}\text { Likert scale rating } \\
\text { option }\end{array}$ & $\begin{array}{c}1 \\
\text { Strongly } \\
\text { disagree }\end{array}$ & $\begin{array}{c}2 \\
\text { Disagree }\end{array}$ & $\begin{array}{c}3 \\
\text { Neither } \\
\text { agree nor } \\
\text { disagree }\end{array}$ & $\begin{array}{c}4 \\
\text { Agree }\end{array}$ & $\begin{array}{c}5 \\
\text { Strongly } \\
\text { agree }\end{array}$ \\
\hline $\begin{array}{l}\text { The cost to design } \\
\text { and implement } A B C \\
\text { is too high }\end{array}$ & 2 & 1 & 5 & 5 & 0 \\
\hline$A B C$ is too complex & 0 & 2 & 3 & 7 & 1 \\
\hline $\begin{array}{l}\text { Too difficult to } \\
\text { develop suitable } \\
\text { cost drivers and cost } \\
\text { pools }\end{array}$ & 0 & 1 & 5 & 7 & 0 \\
\hline $\begin{array}{l}\text { There is no senior } \\
\text { management } \\
\text { commitment to a } \\
\text { tool such as } A B C\end{array}$ & 0 & 1 & 6 & 6 & 0 \\
\hline $\begin{array}{l}\text { It would be } \\
\text { necessary to create } \\
\text { a new system for } \\
\text { data capturing and } \\
\text { processing }\end{array}$ & 0 & 0 & 3 & 9 & 1 \\
\hline
\end{tabular}




\begin{tabular}{|c|c|c|c|c|c|}
\hline $\begin{array}{l}\text { Likert scale rating } \\
\text { option }\end{array}$ & $\begin{array}{c}1 \\
\text { Strongly } \\
\text { disagree }\end{array}$ & $\begin{array}{c}2 \\
\text { Disagree }\end{array}$ & $\begin{array}{c}3 \\
\text { Neither } \\
\text { agree nor } \\
\text { disagree }\end{array}$ & $\begin{array}{c}4 \\
\text { Agree }\end{array}$ & $\begin{array}{c}5 \\
\text { Strongly } \\
\text { agree }\end{array}$ \\
\hline $\begin{array}{l}A B C \text { is limited in its } \\
\text { ability to explain } \\
\text { cost variability }\end{array}$ & 1 & 1 & 6 & 5 & 0 \\
\hline $\begin{array}{l}\mathrm{ABC} \text { is limited in its } \\
\text { ability to assist cost } \\
\text { control }\end{array}$ & 2 & 1 & 5 & 5 & 0 \\
\hline
\end{tabular}

Source: Authors' analysis

In South Africa the cost of designing and implementing $A B C$ was not cited as a reason not to consider $A B C$, whereas in Ireland this was highlighted as the most significant reason not to consider the adoption of $A B C$. The complexity of $A B C$ was highlighted in the studies in both Ireland and South Africa, but was not cited in the USA study. The belief that $A B C$ will necessitate a new system for data capture and processing was cited by all three studies as a reason not to adopt $A B C$. The lack of senior management support did not feature in the South African survey, whereas this was highlighted as one of the most important reasons not to consider the adoption of $A B C$ in the USA study. The reasons highlighted in this survey not to consider the adoption of $A B C$ are mostly in line with those identified in the surveys conducted in the USA and Ireland.

\subsection{The perceived and realised benefits of adopting $A B C$}

The questionnaire asked respondents about the perceived benefits they can derive if they adopt $A B C$ and thereafter the actual benefits which realised after they adopted $A B C$. The layout of the questionnaire and the wording of the statements were structured in such a way so as not to distract through repetitiveness and to discourage respondents from giving the same rating for similar perceived and actual benefits. To report the results, generic terms are used for the perceived and actual benefits.

The reported results are for the 19 out of 41 respondents who indicated that their health care facilities fully adopted ABC. TABLE 2 presents the results from an analysis of the questionnaire responses of perceived and actual benefits (sorted in alphabetical order of the benefit identified).

The descriptive statistics show that the perceived benefits expected from $A B C$ differ from the actual benefits which realised after adoption. Even though respondents expected more accurate cost information from $A B C$, it was not the first change they observed afterwards. As can be expected from $A B C$, activities were identified more clearly through the use of $A B C$, ranking that item highest as an actual benefit from $A B C$. Better resource use ranked third as a perceived benefit of the adoption of $A B C$, but ranked second highest as an actual benefit from $A B C$. 
TABLE 2: Perceived and actual benefits as reported by respondents who adopted ABC

\begin{tabular}{|c|c|c|c|c|c|c|}
\hline \multirow[b]{2}{*}{ Benefit identified } & \multicolumn{3}{|c|}{ Perceived benefits } & \multicolumn{3}{|c|}{ Actual benefits } \\
\hline & Mean & $\begin{array}{l}\text { Std. } \\
\text { Deviation }\end{array}$ & Ranking & Mean & $\begin{array}{l}\text { Std. } \\
\text { Deviation }\end{array}$ & Ranking \\
\hline $\begin{array}{l}\text { Better involvement and } \\
\text { control of medical personnel }\end{array}$ & 2.84 & 0.765 & 7 & 3.32 & 0.671 & 7 \\
\hline Better resource use & 4.05 & 0.524 & 3 & 4.16 & 0.501 & 2 \\
\hline $\begin{array}{l}\text { Improved negotiations with } \\
\text { medical aid }\end{array}$ & 3.74 & 1.046 & 6 & 3.74 & 0.991 & 5 \\
\hline $\begin{array}{l}\text { Improvement in total quality } \\
\text { management }\end{array}$ & 4.05 & 1.079 & 4 & 3.89 & 0.737 & 4 \\
\hline $\begin{array}{l}\text { Insight into activities that } \\
\text { drive cost }\end{array}$ & 4.37 & 0.496 & 2 & 4.47 & 0.513 & 1 \\
\hline $\begin{array}{l}\text { More accurate cost } \\
\text { information }\end{array}$ & 4.42 & 0.507 & 1 & 4.16 & 0.834 & 3 \\
\hline $\begin{array}{l}\text { Useful information for } \\
\text { process improvements }\end{array}$ & 3.89 & 0.315 & 5 & 3.68 & 0.671 & 6 \\
\hline
\end{tabular}

Source: Authors' analysis

A One-Sample Kolmogorov-Smirnov test was performed for each pair of statements of perceived and actual benefits. The test results indicate that the responses are normally distributed and show a significant relationship for each pair. Further detailed statistical analysis apart from frequency distributions and descriptive statistics were deemed unnecessary for purposes of this study.

\subsection{The problems experienced with the adoption of $A B C$}

The main reasons for adopting $A B C$ at a health care facility level indicate that health care facilities are aware of the importance of controlling costs in order to maintain and improve profitability. Furthermore, the reasons cited for the adoption of $A B C$ at a health care facility level in South Africa are in line with those given in surveys conducted in the USA and Ireland.

Respondents were given the opportunity to rate various problems that are generally experienced in the adoption of an $A B C$ system. The results from the respondents' feedback in terms of frequencies are presented in $T A B L E 3$. Responses reported are again for the 19 out of 41 respondents who indicated that $A B C$ has been adopted fully.

Through a review of the frequency of responses to statements related to problems experienced in the processes to adopt $A B C$, one can observe that most respondents rated the statements with a 2 (Disagree). This can be an indication that the problems mentioned in the questionnaire may not have expressed clearly the issues faced by the different health care facilities or that very few problems were experienced. 
TABLE 3: Problems experienced in the adoption ABC

\begin{tabular}{|c|c|c|c|c|c|}
\hline Likert scale rating option & $\begin{array}{l}1 \\
\text { Strongly } \\
\text { disagree }\end{array}$ & $\begin{array}{c}2 \\
\text { Disagree }\end{array}$ & $\begin{array}{c}3 \\
\text { Neither } \\
\text { agree nor } \\
\text { disagree }\end{array}$ & $\begin{array}{c}4 \\
\text { Agree }\end{array}$ & $\begin{array}{l}5 \\
\text { Strongly } \\
\text { agree }\end{array}$ \\
\hline $\begin{array}{l}\text { Lack of adequate resources to } \\
\text { effectively implement } A B C\end{array}$ & 0 & 8 & 6 & 5 & 0 \\
\hline $\begin{array}{l}\text { Difficulty in selling the } \\
\text { concept to senior management }\end{array}$ & 2 & 13 & 1 & 3 & 0 \\
\hline $\begin{array}{l}\text { Difficulty in selling the } \\
\text { concept to middle } \\
\text { management }\end{array}$ & 2 & 13 & 0 & 4 & 0 \\
\hline $\begin{array}{l}\text { Difficulty in selling the } \\
\text { concept to doctors }\end{array}$ & 1 & 5 & 9 & 3 & 1 \\
\hline $\begin{array}{l}\text { Difficulty in selling the } \\
\text { concept to other medical staff }\end{array}$ & 1 & 7 & 6 & 4 & 1 \\
\hline $\begin{array}{l}\text { Difficulty in allocating costs to } \\
\text { activities that directly drive } \\
\text { and impact cost behaviour }\end{array}$ & 2 & 8 & 3 & 6 & 0 \\
\hline $\begin{array}{l}\text { Difficulty in selecting cost } \\
\text { drivers }\end{array}$ & 0 & 12 & 3 & 4 & 0 \\
\hline $\begin{array}{l}\text { Difficulty in defining distinct } \\
\text { activities }\end{array}$ & 0 & 14 & 1 & 3 & 1 \\
\hline $\begin{array}{l}\text { Difficulty associated with } \\
\text { gathering the information } \\
\text { needed to implement } A B C\end{array}$ & 0 & 12 & 3 & 4 & 0 \\
\hline $\begin{array}{l}\text { Difficulty associated with the } \\
\text { information system }\end{array}$ & 0 & 12 & 2 & 5 & 0 \\
\hline $\begin{array}{l}\text { Inadequate computer system } \\
\text { support to implement the } \\
\text { system }\end{array}$ & 1 & 11 & 2 & 4 & 1 \\
\hline $\begin{array}{l}\text { Lack of in-house skills, high } \\
\text { staff turnover }\end{array}$ & 1 & 11 & 3 & 4 & 0 \\
\hline
\end{tabular}

Source: Authors' analysis

The problems that were experienced by a few health care facilities were difficulties in convincing personnel of the benefits, difficulties in identifying activities and allocating costs, and problems in the set-up of information/computer systems. 


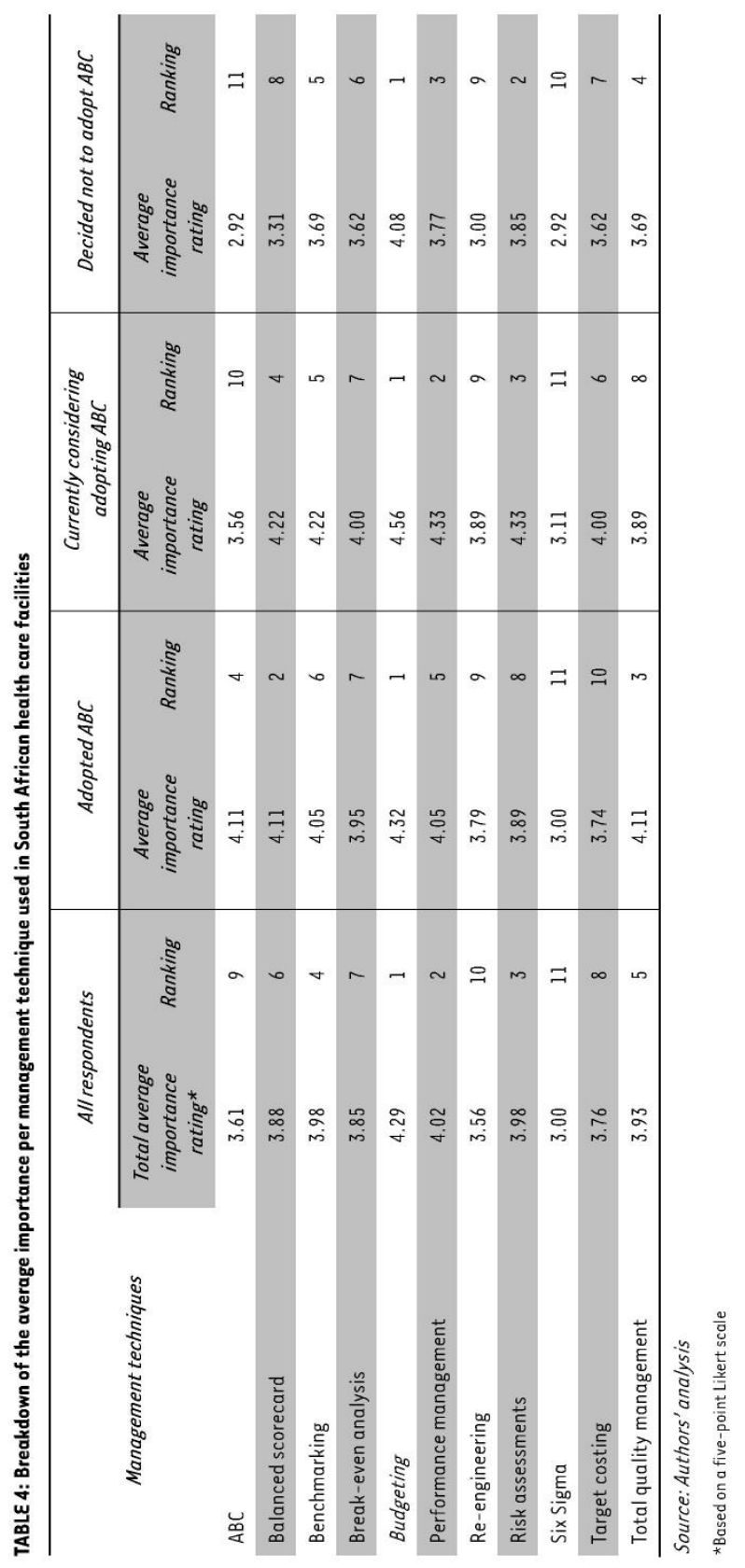




\subsection{Other management accounting techniques that are considered useful}

Health care facilities, like any organisation, do not use only $A B C$ as a management tool to run their business. The level of use of a management tool and technique has a strong correlation to its perceived usefulness (Stratton, Lawson and Hatch, 2004). The tables that follow provide information about the rankings of different management tools and techniques. The results are reported for all the respondents, as well as per group (based on the adoption of $A B C$ ).

The top most commonly preferred (and possibly used) management tool and technique identified by all health care facility respondents, irrespective of their $A B C$ adoption status, was budgeting. It is of some concern that the overall ranking for $A B C$ was relatively low, even for respondents who indicated that $A B C$ was adopted at their facilities.

The three most commonly used management tools and techniques identified by all health care facility respondents in the USA on the average importance rating in order of importance were budgeting, benchmarking and break-even analysis (Lawson, 2005). This differs for South Africa, with $A B C$ ranked fourth out of a possible nine management tools and techniques by all health care respondents that have adopted $A B C$. Those that have adopted $A B C$ rank as their top three budgeting, balanced scorecard and total quality management.

TABLE 4 also shows that there is a distinct difference between the different management tools and techniques used in relation to the level of $A B C$ adoption. Irrespective of the level of $A B C$ adoption, budgeting was ranked the most important management tool and technique used by the health care facilities to achieve their vision and targets. $A B C$ was ranked as the fourth most important management tool and technique among the health care facilities that have adopted $A B C$, which indicates that it is seen as a lesser important element to achieve their vision and targets.

\section{CONCLUSION}

The health care industry of South Africa is set to undergo many changes over the next few years to accommodate the possibility of new fee regulations implemented and also the impact that the $\mathrm{NHI}$ may have on the number of medical aid patients who will be able to afford hospital care. The implementation of a NHI in South Africa brings with it increased responsibility by hospitals to provide quality cost information. Activity Based Costing $(A B C)$ is one option to ensure that costs are captured accurately and allocated to the correct activity that causes the cost.

The increase in the $A B C$ adoption rate of $29.8 \%$ over a twenty-year period indicates that people are aware of the benefits of $A B C$ and its use is encouraged widely. Even though perceived and actual benefits in the adoption of $A B C$ differ, it is still thought to be a useful tool through the benefits it provides. All the benefits, perceived and actual, received a relatively high Likert-scale rating, rendering none of the benefits obsolete.

As with any management tool, $A B C$ does pose its share of challenges. However, none of the respondents indicated significant problems in the implementation of $A B C$, but only minor issues that are relatively easy to resolve.

It is important to notice that $A B C$ is most often only one tool out of many that are used by organisations. The ranking of different management tools and techniques has indicated that $A B C$ is not on top of the list, but that traditional tools such as budgeting still rank highly. However, the 
number of respondents who are considering the adoption of $A B C$ in their health care facilities supports this statement.

The South African health care industry is set for change in years to come. With the adoption of leading management tools and techniques such as $A B C$, the health care industry will be able to cope with these changes and challenges in an effective manner.

\section{LIMITATIONS TO THE STUDY AND SUGGESTED FUTURE RESEARCH}

This study did not consider public health care facilities. A study should be undertaken to determine the level of $A B C$ adoption within public health care facilities, as $A B C$ could improve cost control and resource usage within these facilities too.

The complexity that is associated with $A B C$ has brought about a revised, simpler form of $A B C$, namely time-driven activity-based costing (TDABC), which was developed by Kaplan and Anderson (2003). Future research should be undertaken to determine the extent to which TDABC is used and implemented or considered for use in health care facilities in South Africa.

That most respondents answered 2 (disagree) in the survey could be considered a gap in the research, as it is important to understand the difficulties faced by health care facilities in South Africa with the adoption of $A B C$. If the difficulties in the adoption of $A B C$ can be properly understood, future research could assist with methods to apply $A B C$ with greater success.

A reason for $A B C$ not being considered as one of the top three management accounting tools (ranked fourth) can also be due to a lack of education on the usefulness of the information derived from an $A B C$ system and how powerful a tool it can be to assist in the reduction of strategic management issues faced by health care facilities.

\section{LIST OF REFERENCES}

Akay, M. and Tamura, T. (2015). Global Healthcare: Advances and Challenges (Scanning the Issue), Proceedings of the Iદદદ, 103, pp. 147-149.

Alhabeeb, M. J. (2012). Break-Even Analysis, in Mathematical Finance, Hoboken (NJ): John Wiley.

Bateman, C. (2010), How will NHI affect my practice? Workshop seeks answers. South African Medical Journal, $100(6)$, pp. 350-352.

Burrows, G. and Chenhall, R. H. (2012). Target costing: First and second comings. Accounting History Review, 22(2), pp. 127-142.

Cescon, F., Costantini, A. and Rossi, G. (2013). The influence of business strategy and ownership on management accounting innovations and risk management techniques: An empirical analysis in large manufacturing companies in Italy. Udine, Italy: University of Udine, Department of Economics and Statistics.

Chenhall, R. H. and Langfield-Smith, K. (1998). Adoption and benefits of management accounting practices: an Australian study. Management Accounting Research, 9(1), pp. 1-19.

Chiarini, A. (2012). From Total Quality Control to Lean Six Sigma. Milan: Springer. 
De Waal, A. (2013). Strategic Performance Management: A managerial and behavioral approach. London: Palgrave Macmillan.

Dereli, T., Durmuşoğlu, A., Delibaș, D. and Avlanmaz, N. (2011). An analysis of the papers published in total quality management \& business excellence from 1995 through 2008. Total Quality Management, 22(3), pp. 373-386.

Doyle, G., Duffy, L. and McCahey, M. (2007). An empirical study of adoption/non-adoption of activity based costing in hospitals in Ireland. Canada: Dalhousie University.

Eldenburg, L., Soderstrom, N., Willis, V. and Wu, A. (2010). Behavioral changes following the collaborative development of an accounting information system. Accounting, Organizations and Society, 35(2), pp. 222-237.

Evans, J. and Lindsay, W. (2014). An introduction to Six Sigma and process improvement. Boston, (MA): Cengage Learning.

Garg, A., Ghosh, D., Hudick, J. and Nowacki, C. (2003). Roles and practices in management accounting today. Strategic Finance, 85(1), pp. 30.

Gruman, J. A. and Saks, A. M. (2011). Performance management and employee engagement. Human Resource Management Review, 21(2), pp. 123-136.

Gupta, K. and Kumar, G. (2014). Six sigma application in warehouse for damaged bags: A case study. Reliability, Infocom Technologies and Optimization (ICRITO) - Trends and Future Directions. 3rd International Conference 2014. Iદદદ, 1-6.

Hoque, Z., Nørreklit, H., Nørreklit, L., Mitchell, F. and Bjørnenak, T. (2012). The rise of the balanced scorecard! Relevance regained? Journal of Accounting \& Organizational Change, 8(4), pp. 490-510.

Kaplan, R. and Anderson, S. (2003). Time-driven activity-based costing. Available at SSRN 485443, November, pp. 18.

Kaplan, R. and Cooper, R. (1997). Cost and Effect: Using Integrated Cost Systems to Drive Profitability and Performance. Boston (MA): Harvard Business School Press.

Kaplan, R. S. and Norton, D. P. (2001). The strategy-focused organization. Strategy and Leadership, 29(3), pp. 41-42.

Kaplan, R. S. and Porter, E. M. (2011). How to solve the cost crisis in healthcare. Harvard Business Review, September 2011, pp. 15.

Kiani, R. and Sangeladji, M. (2003). An empirical study about the use of the ABC/ABM models by some of the Fortune 500 largest industrial corporations in the USA. Journal of American Academy of Business, 3(1/2), pp. 174-182.

King, M., Lapsley, I., Mitchell, F. and Moyes, J. (1994). Costing needs and practices in a changing environment: the potential for $\mathrm{ABC}$ in the NHS. Financial Accountability \& Management, 10(2), pp. $143-160$.

Lawson, R. (2005). The use of activity based costing in the healthcare industry: 1994 vs. 2004. Research in healthcare financial management, 10(1), pp. 77.

Lewis, P., Thornhill, A. and Saunders, M. (2007). Research methods for business students. Harlow: Pearson.

Llewellyn, S. and Northcott, D. (2005). The average hospital. Accounting, Organizations and Society, $30(6)$, pp. 555-583. 
Luther, R. G. and Longden, S. (2001). Management accounting in companies adapting to structural change and volatility in transition economies: a South African study. Management Accounting Research, 12(3), pp. 299-320.

Makholwa, A. (2013a). Life is tough. Financial Mail, 25 April 2013.

Makholwa, A. (2013b). Seeking a remedy. Financial Mail, 5 July 2013.

Niven, P. R. (2011). Balanced scorecard: Step-by-step for government and non-profit agencies, Hoboken (NJ): John Wiley.

Paape, L. and Speklè, R. F. (2012). The adoption and design of enterprise risk management practices: An empirical study. European Accounting Review, 21(3), pp. 533-564.

Pandey, S. (2012). Applying the ABCs in provider organizations. Journal of the Healthcare Financial Management Association, 66(11), pp. 112-119.

Pizzini, M. J. (2006). The relation between cost-system design, managers' evaluations of the relevance and usefulness of cost data, and financial performance: an empirical study of US hospitals. Accounting, Organizations and Society, 31(2), pp. 179-210.

Porter, M. E. and Lee, T. H. (2013). The strategy that will fix health care. Harvard Business Review, 9l(10), pp. 50-70.

Ramsey, R. H. (1994). Activity-based costing for hospitals. Journal of Healthcare Management, 39(3), pp. 385.

Richards, J. (2012). Total Quality Management. Business Management and Strategy, 3, pp. 36-42.

Ross, T. K. (2003). Analyzing health care operations using ABC. Journal of health care finance, 30 (3), pp. 1-20.

Salomon, J. A., Wang, H., Freeman, M. K., Vos, T., Flaxman, A. D., Lopez, A. D. and Murray, C. J. L. (2013). Healthy life expectancy for 187 countries, 1990-2010: a systematic analysis for the Global Burden Disease Study 2010. The Lancet, 380(9859), pp. 2144-2162.

Stratton, W., Lawson, R. A. and Hatch, T. (2004). Scorecarding as management coordination and control system. Cost Management, pp. 36-42.

Swink, M. and Jacobs, B. W. (2012). Six Sigma adoption: Operating performance impacts and contextual drivers of success. Journal of Operations Management, 30(6), pp. 437-453.

Tang, S., Tao, J. and Bekedam, H. (2012). Controlling cost escalation of healthcare: making universal health coverage sustainable in China. BMC Public Health, 12(1), pp. 58.

The World Bank. (2014). Health Expenditure, total (\% of GDP). Available: http://data.worldbank.org/indicator/SH.XPD.TOTL.ZS [Accessed 27-05-2015].

Tsorakidis, N., Papadoulos, S., Zerres, M. and Zerres, C. (2011). Break-Even Analysis. Bookboon.

Udpa, S. (1996). Activity-based costing for hospitals. Health Care Management Review, 21(3), p. 83.

Viljoen, M. (1994). Die toepassing van aktiwiteitsgebaseerde kosteberekening in privaat hospitale in Suid Afrika. Unpublished master's dissertation. Potchefstroom: Potchefstroom University.

Wasserman, H. (2010). Doctor's orders: five ways to prepare for the NHI. Finance Week, 11 November 2010.

Welman, C., Kruger, F. and Mitchell, B. (2005). Research methodology. Cape Town: Oxford University Press. 
THE ADOPTION OFACTIVITY-BASED COSTING IN PRIVATE HEALTH CARE FACILITIES IN SOUTH AFRICA

West, T. D. and West, D. A. (1997). Applying ABC to healthcare. Strategic Finance, 78(8), pp. 22. 